\title{
Horner-s Syndrome following common carotid artery translocation in a horse: case report
}

[Síndrome de Horner após transposição de carótida em equino: relato de caso]

\author{
C.M.M. Coelho ${ }^{1}$, M.C.S. Lopes $^{2}$, F.N. Flôres ${ }^{3}$, D. Zangirolami Filho ${ }^{1}$, \\ P.A. Canola ${ }^{1}$, C.A.A. Valadão ${ }^{1}$ \\ ${ }^{1}$ Universidade Estadual Paulista Júlio de Mesquita Filho - Jaboticabal, SP \\ ${ }^{2}$ Universidade Federal da Bahia - Salvador, BA \\ ${ }^{3}$ Universidade Federal de Roraima - Boa Vista, RR
}

\begin{abstract}
Horner's syndrome (HS) is a sympathetic dysfunction caused by injuries to the sympathetic pathway. A clinical case of HS following common carotid artery transposition and catheterization in a horse is described. The animal presented head and neck sweating with focal skin temperature elevation, facial paralysis and ptosis. Most clinical signs were transient and persisted for two hours following percutaneous catheter removal. Recurrence of clinical signs was observed at subsequent catheterizations. Ptosis endured for 10 months as a consequence of the first catheter placement which demonstrates the importance of careful manipulation of the anatomical structures of the neck when performing any surgical manipulation in this area.
\end{abstract}

Keywords: horse, neurologic disorders, sympathetic trunk, nerve dysfunctions

\section{RESUMO}

A síndrome de Horner é uma disfunção do sistema nervoso autônomo simpático, decorrente de qualquer injúria a essa via de transmissão nervosa. Este artigo descreve um caso da síndrome após cirurgia para a transposição da artéria carótida comum. Os sinais clínicos observados foram sudorese de face e pescoço, com hipertermia localizada, paralisia facial e ptose palpebral. A maioria dos sinais foi transitória e se manifestou por até duas horas após a remoção do cateter percutâneo, introduzido na artéria transposta. Como essa manifestação foi recorrente nas venóclises subsequentes e a ptose palpebral perdurou por 10 meses, desde a primeira punção arterial, ressalta-se a importância e o critério quando da necessidade de manipulação cirúrgica dessa região anatômica.

Palavras-chave: cavalo, desordem neurológica, tronco simpático, disfunção nervosa

\section{INTRODUCTION}

A minimum knowledge of the autonomic nervous system morphophysiology is mandatory when one seeks understanding of Horner's Syndrome (HS). Any lesion to this pathway may cause HS including damage to the cervical sympathetic trunk in the neck, the cranial cervical ganglion in the guttural pouch and the cervicothoratic (stellate) ganglion in the cranial thorax (Skarda et al., 1986; Jones, 1989; Green et al., 1992; Murray et al., 1997). The clinical

Recebido em 17 de abril de 2013

Aceito em 19 de fevereiro de 2014

E-mail: cassiamaria.coelho@gmail.com signs most commonly observed in horses are increased skin temperature and sweating of the head and neck, and less commonly ptosis, miosis, enophtalmos and third eyelid protrusion on the ipsilateral side. In addition, the dilation of facial blood vessels and nasal and conjuntival mucous membrane hyperemia may develop (Jones, 1989; Hahn, 2006).

In equine veterinary practice, the jugular groove (vein) and neck musculature are two important sites for intravenous and intramuscular administration of drugs, respectively, that may be 
a factor in accounting for some cases of iatrogenic Horner's Syndrome in this species. This report describes a transitory and intermittent case of Horner's Syndrome in a horse following common carotid artery catheterization (Tavernor, 1969), previously relocated for research purposes.

\section{CASE DESCRIPTION}

A seven year old mixed breed mare, considered healthy based on clinical examination and hematology was used for experimental left common carotid translocation. This procedure was performed to facilitate serial (and directly acquired) arterial blood pressure measurement as well as arterial blood sampling for purposes of long term blood gas analysis. The anesthetic protocol included premedication with xylazine $(1.0 \mathrm{mg} / \mathrm{kg}$ IV) followed by guaiphenesin $(100 \mathrm{mg} / \mathrm{kg} \mathrm{IV})$ with midazolam $(0.3 \mathrm{mg} / \mathrm{kg} \mathrm{IV})$. Final induction was accomplished with ketamine $\quad(2.0 \mathrm{mg} / \mathrm{kg} \quad$ IV $)$ administration. Anesthetic maintenance was with isofluorane (1-1.5 MAC) on oxygen. The surgical procedure was performed as previously described (Tavernor, 1969). Preceding isolation of the vagosympathetic trunk from the left common carotid artery, $10 \mathrm{~mL}$ of lidocaine $2 \%$ was instilled on the surgical site to prevent increase in autonomic tonus (sympathetic or parasympathetic). Anesthetic recovery was without complications. Post-surgical care included daily cleaning of the surgical site, flunixim meglumine $(0.5 \mathrm{mg} / \mathrm{kg}$ bid IV) for three days and enrofloxacin $(2.5 \mathrm{mg} / \mathrm{kg}$ bid IV) for 10 days.

Thirty days following surgery arterial catheterization was performed by insertion of a $16 \mathrm{G}, 45 \mathrm{~mm}$ percutaneous catheter. Within 15 minutes focal sweating located on the left side of the face and at the proximal portion of the neck was observed (Figure 1). Ptosis of the left upper eyelid and excessive skin warmth on the left side of the face were evident and evaluated by symmetrical comparison with the ipslateral side and hand touch, respectively. A discreet muzzle deviation to the right (suggestive of facial paralysis) was also noted (Figure 2). However, no anisocoria or loss of pupillary reflexes was observed. The catheter was maintained in the common carotid artery for a period of 2 hours and the clinical signs (mainly sweat and warmth) persisted for approximately 6 hours following catheter removal.

A fifteen-day washout interval was established between the first and second attempt of arterial catheterization. On the second occasion, facial and neck sweating and warmth were presented and persisted for the same period as the initial attempt. A third attempt was performed fifteen days later. The same previously observed clinical signs following catheterization were noticed as well. Ptosis originated on the first catheterization attempt was still present at this moment. However, it gradually diminished following cessation of arterial puncturing attempts. Complete absence of clinical signs was only confirmed 10 months after the first catheterization attempt.

\section{DISCUSSION}

Horner's syndrome is a fairly common clinical manifestation that has been described in horses, as well as other species, as a cause of careless jugular venipuncture or perivascular injection (Sweeney and Sweeney, 1984; Jones, 1989; Green et al., 1992). It's appearance has also been related to the presence of thoracic masses, guttural pouch diseases and traumas to the head and neck (Milne, 1986; Green et al., 1992; Murray et al., 1997). In our case, the HS symptoms appeared shortly following arterial catheter placement and persisted for days in between catheterizations. These observations suggest that HS manifestation was triggered by arterial catheterization and not by the heparinized saline solution instilled within the common carotid artery for catheter maintenance during arterial blood pressure measurement (a total volume was less than $5 \mathrm{~mL}$ in a 2 hour period). The use of 16-gauge catheters are preferred and used routinely in our laboratory, because the animals are kept catheterized in between pressure acquisitions. Small-sized catheters increase catheter failure in this period because they seem more prone to kinking or dislodgment (personal observation).

A previous report (Green et al., 1992) described two HS cases in horses that had undergone carotid ligation in preparation for ethmoidal hematoma removal. Clinical signs of Horner's syndrome were noticed upon anesthetic recovery which was not so in our case. Nevertheless, it 
should be recalled that clinical signs of HS are similar to those routinely observed in horses during anesthetic recovery including ptosis, anesthetic-induced peripheral vasodilation and sweating and pressure-induced facial paralysis due to recumbency (Muir and Hubbell, 2009). Therefore, it is possible that clinical signs were confounded with usual anesthetic recovery alterations.

The most common clinical signs of acute sympathetic denervation in horses are focal sweating and increased skin temperature, as observed in our patient. Frequently, markedly sweating persists for 24 to 48 hours. Thereafter, patchy sweating can be induced by exciting the animal, thus increasing circulating adrenaline levels (Hahn, 2006). Sweating probably occurs as a result hypersensitivity of beta2-receptors to circulating catecholamines (Bijman and Quinton, 1984). Although HS can be transient and completely resolved in a relatively short period of time, clinical sings can persist for 10 to 15 months, leading to an aesthetically undesirabe appearance (Green et al., 1992).

Another obvious and persistent clinical sign was the ptosis. Ophthalmic disturbances associated with HS have already been mentioned in several species (Jones, 1989). In small animals (dogs and cats) as well as in humans, Horner's Syndrome is clinically confirmed by evaluating pupillary responses to topical and direct-acting noradrenergic agonists (Smith and Smith, 1999). However, horses have been shown to have variable or absent pupillary response to both sympathetic denervation and topical administration of sympathetic agonists (Simoens et al., 1990). Additionally, facial paralysis has been associated with facial cranial nerve dysfunction. However, this clinical feature has not been habitually observed in equine patients with HS (Hahn, 2006). A discrete muzzle deviation was observed in our patient, and most likely was caused by head trauma (Green et al., 1992).

It is possible that tension to or fixation of the sympathetic trunk occurred during common carotid artery translocation. This likely explains the fact that every carotidal catheterization resulted in the occurrence of clinical signs of nerve damage, consistent with HS. Therefore, this fact demonstrates the importance of careful manipulation of the anatomical structures of the neck when performing common carotid artery translocation.

\section{REFERENCES}

BIJMAN, J.; QUINTON, P.M. Predominantly betaadrenergic control of equine sweating. Am. $J$. Physiol., v.246, p.349-353, 1984.

GREEN, S.L.; COCHRANE, S.L.; COCHANE, S.M.; SMITH-MAXIE, L. Horner's syndrome in ten horses. Can. Vet. J., v.33, p.330-333, 1992.

HAHN, C.N. Miscellaneous disorders of the equine nervous system: Horner's Syndrome and Polyneuritis Equi. Clinical Tech Equine Pract, v.5, p.43-48, 2006.

JONES, S.M.P. Neuro-ophthalmology. Br. Vet. J., v.145, p.99-120, 1989.

MILNE, J.C. Malignant melanomas causing Horner's syndrome in a horse. Equine Vet., v.18, p.74-75, 1986.

MUIR, W.W.; HUBBELL, J.A.E. Anestheticassociated complications. In: MUIR, W.W.; HUBBELL, J.A.E. (eds). Equine Anesthesia Monitoring and Emergency Therapy. St Louis: Saunders Elsevier, 2009. p.397-417.

MURRAY, M.J.; CAVEY, D.M.; FELDMAN, B.F. et al. Signs of sympathetic denervation associated with a thoracic melanoma in a horse. J. Vet. Intern. Med., v.11, p.199-203, 1997.

SIMOENS, P.; LAUWERS, H.; DE MUELENARE, C. et al. Horner's syndrome in the horse: a clinical, experimental and morphological study. Equine Vet. J., v.22, p.62-66, 1990.

SKARDA, R.T.; MUIR, W.W.; SWANSON, C.R.; HUBBELL, J.A. Cervicothoracic (stellate) ganglion block in conscious horses. Am. J. Vet. Res., v.47, p.21-26, 1986.

SMITH, S.A.; SMITH, S.E. Bilateral Horner's syndrome: detection and occurrence. J. Neurol. Neurosurg. Psychiatry, v.66, p.48-51, 1999.

SWEENEY, R.W.; SWEENEY, C.R. Transient Horner's syndrome following routine intravenous injections in two horses. J. Am. Vet. Med. Assoc., v.185, p.802-807, 1984.

TAVERNOR, W.D. Technique for the subcutaneous relocation of the common carotid artery in the horse. AJVR, v.30, p.1881-1883, 1969. 